\title{
Positive impact of bio-stimulators on growth and physiological activity of willow in climate change conditions
}

\author{
Krzysztof Piotrowski and Zdzisława Romanowska-Duda* \\ Laboratory of Plant Ecophysiology, Faculty of Biology and Environmental Protection, University of Łódź, Banacha 12/16 \\ 90-237 Łódź, Poland
}

Received November 24, 2017; accepted December 29, 2017

\begin{abstract}
The aim of this research was to evaluate the physiological activity and growth of willow (Salix viminalis L.) plants cultivated under the conditions of adverse temperature and soil moisture content, and to assess the effect of the foliar application of Biojodis (1.0\%) and Asahi SL (0.03\%) bio-stimulators, or a mixture of Microcistis aeruginosa MKR 0105 and Anabaena PCC 7120 cyanobacteria under such changing growth conditions. The obtained results showed different reactions to the applied constant or periodically changed temperature and soil moisture content. The plants which grew at periodically changed adverse temperature (from -5 to $40^{\circ} \mathrm{C}$ ) or in scantily $(20 \%$ m.c.) or excessively ( $60 \%$ m.c.) watered soils, grew slowly, in comparison with those growing at $20^{\circ} \mathrm{C}$ and in optimally moistened soil $(30 \%$ m.c.). Foliar application of Biojodis and Asahi SL cyanobacteria increased the growth of willow at optimal and adverse temperature or in scantily and excessively moistened soil. The changes in plant growth were associated with the changes in electrolyte leakage, activity of acid or alkaline phosphatases, RNase, index of chlorophyll content in leaves and gas exchange. The above indicates that the foliar application of the studied cyanobacteria and bio-stimulators partly alleviates the harmful impact of adverse temperature and water stress on growth and physiological activity of willow plants.
\end{abstract}

Keyw ords: willow, bio-stimulators, growth, physiological activity

\section{INTRODUCTION}

Willow (Salix viminalis L.) is one of the more important crops cultivated for energy purposes in central and northern Europe. There are concerns that with the progressive climate changes increasing deficit of water in soil and resulting in inadequate rainfalls, the area favourable for the cultivation of this species will decrease. In addition, the

*Corresponding author e-mail: romano@biol.uni.lodz.pl use of large quantities of chemical fertilizers, to achieve high yields of willow biomass, creates a risk of their run-off into water reservoirs, causing pollution of soil and water. Therefore, various methods of treatment and substances that do not contaminate the environment while simultaneously having a beneficial effect on growth of plants and increasing their resistance to adverse temperature and soil aridity have become the focus of interest (Wu et al., 2017). The application of bio-stimulators and natural fertilizers in energy crops are alternatives to synthetic fertilizers, and these have a positive impact on the environment (Ananieva et al., 2004; Grzesik et al., 2015; Piotrowski et al., 2016a, b).

Non-toxic cyanobacteria are an alternative to synthetic substances. Their use in the future-oriented ecological agriculture is highly promising (Grzesik and RomanowskaDuda, 2014). Cyanobacteria are able to synthesize many compounds, i.a. amino acids, carbohydrates, micro and macroelements, auxin (IAA), gibberellins (GA), cytokinin, vitamins and several other secondary metabolites, which, when absorbed by plants, regulate their growth. Moreover, they have the ability to assimilate atmospheric nitrogen while having important impact on plant development. Previous studies have shown that the effectiveness of plant hormones of microbial origin was comparable to that of standard cytokinins and IAA. Cyanobacteria are commonly found in the natural environment and can be cultured on a large production scale with the use of appropriate technology (Hussain and Hasnain, 2012). Selected species of cyanobacteria have been observed to have beneficial effect on the growth of some energy crops cultivated under favourable environmental conditions (Grzesik et al.,

(C) 2018 Institute of Agrophysics, Polish Academy of Sciences 
2015; Piotrowski et al., 2016a, b). However, information about the impact of a mixture of cyanobacteria species on the energy crop growth under adverse temperature and soil moisture conditions is very limited.

The research performed on vegetables (Virginia mallow and corn) has revealed the beneficial impact of the Biojodis and Asahi SL bio-stimulators on the growth of these plants under different environmental conditions. Such bio-stimulators have also been noted to enhance the plants' ability to increase resistance to adverse temperatures and soil water shortage (Anyszka et al., 2008; Gawrońska et al., 2008; Jeznach, 2011; Piotrowski et al., 2016a, b). Biojodis is a liquid extract that is manufactured on the basis of biohumus. It contains active iodine present in the form of ions $\left(\mathrm{JO}_{3}\right.$ and $\left.\mathrm{J}\right)$ which have a strong stimulating impact on the growth of the soil bacteria responsible for the organic-mineral complex (Babik, 2006; Grzesik et al., 2011; Grzesik and Romanowska-Duda, 2009). Asahi SL is another biostimulant recommended in vegetable plant production. It is a compound based on three active substances from the nitrophenol group that naturally occur in plants (sodium ortho-nitrophenolan ONP $(0.2 \%)$, sodium para-nitrophenolan PNP $(0.3 \%)$ and sodium 5-nitroguajakolan 5NG (0.1\%) (Grzesik et al., 2009). According to the literature data, horticultural plants sprayed with Asahi SL exhibit improved growth and higher yield. The latter is the result of higher efficiency of gas exchange, as well as increased water and organic compound content (Anyszka et al., 2008; Gawrońska et al., 2008). It should be noted that tuber content of polyphenols is affected by cultivars, herbicides and bio-stimulants as well as weather conditions during the growing season. Indeed, herbicides and bio-stimulants increase the concentration of polyphenol compounds compared with control tubers (Zarzecka et al., 2017).

Still, while some knowledge of the effect of cyaobacteria and the aforementioned bio-stimulators is known in horticultural crops, information concerning the effect of cyanobacteria, as well as Biojodis and Asahi SL bio-stimulators on energy willow growth under adverse temperature and soil moisture conditions is hard to find in literature.

The aim of this research was to investigate the effect of a mixture of cyanobacteria monocultures (Microcistis aeruginosa MKR 0105 and Anabaena PCC 7120) or Asahi SL and Biojodis bio-stimulators on the growth and physiological activity of willow (Salix viminalis L.) cultivated under the adverse temperature and soil moisture conditions which seem likely to appear in Europe in the near future.

\section{MATERIAL AND METHODS}

The cuttings were rooted and the obtained plants were grown in 31 pots filled with a mixture of sand and peat $(1: 1=\mathrm{v}: \mathrm{v})$. The pots were kept in growth chambers under constant or periodically changed temperature and soil moisture content (m.c.) conditions. These were as follows:

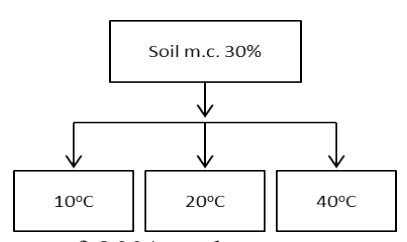

constant soil m.c. of $30 \%$ and temperatures of 10,20 and $40^{\circ} \mathrm{C}$;

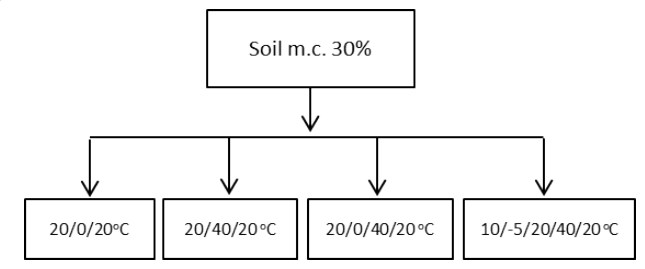

constant soil m.c. of $30 \%$ and changing temperature, during the first month after rooting of the cuttings, in 1-week intervals: $20 / 0 / 20,20 / 40 / 20,20 / 0 / 40 / 20,10 /-5 / 20 / 40 / 20^{\circ} \mathrm{C}$, so as to simulate the temperature changes during spring and the vegetation season. The temperatures of 0 and $-5^{\circ} \mathrm{C}$ were used for $8 \mathrm{~h}$ only to simulate the night light frost in spring;

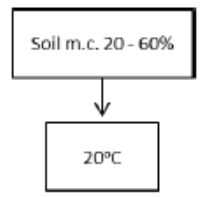

constant temperature of $20^{\circ} \mathrm{C}$ and soil m.c. changed periodically from 20 to $60 \%$ m.c., in 3-week intervals, to simulate aridity and excessive soil moistening during plant growth.

Next the plants were kept at $20^{\circ} \mathrm{C}$ and $30 \%$ soil m.c. up to the end of the vegetation season. The cuttings and plants were kept under an $8 \mathrm{~h}$ dark $16 \mathrm{~h}^{-1}$ light cycle - SON-T AGRO $400 \mathrm{~W}, 100 \mu \mathrm{molm}^{-2} \mathrm{~s}^{-1}$. The moisture content of the soil was evaluated twice a day using a Moisture Meter (Delta-T Devices Ltd) equipped with WET sensors. The media moisture content was expressed as a percentage of volumetric water content (\% vol.) (Gornik and Grzesik, 2002). When needed, the soil was additionally watered to obtain the desired m.c.

During the vegetation season, the selected batches of willow plants grown under the above mentioned conditions were triple-sprayed, in three week intervals, with non-toxic cyanobacteria (a mixture of monocultures of Microcystis aeruginosa MKR 0105 and Anabaena sp. PCC 7120) or Biojodis bio-stimulator (1\%; Jodavita, Lithuania) or Asahi SL bio-stimulator (0.03\%; Asahi Chemical Co Ltd, Japan).

The studied cyanobacteria monocultures were cultivated on BG11 medium (ATCC Medium 616 ) at $27^{\circ} \mathrm{C}$ under FAREL lamp $18 \mathrm{~W}$, according to the procedure elaborated by Romanowska-Duda (Romanowska-Duda et al., 2010). Prior to application, each monoculture was centrifuged for 2 min (4000 r.p.m.) and suspended in water. Then, the number of cells was counted using a Fuchs-Rosenthal hemocytometer. The cell density used in the experiments was estimated to be $2.5 \times 105$ cells ml ${ }^{-1}$ water. 
For each plant treatment, three replicates in three series were prepared and every replicate contained 30 plants grown in 30 separate containers.

The impact of the used cyanobacteria and biostimulators on plant development under adverse temperature and soil moisture content conditions was evaluated on the basis of plant height, electrolyte leakage from leaves, activities of acid and alkaline phosphatases and RNase, index of chlorophyll content and gas exchange in leaves (net photosynthesis, transpiration, stomatal conductance and concentration of intercellular $\mathrm{CO}_{2}$ ). The selected measurements were performed several times during the vegetation season, depending on the intensity of plant growth.

Plant height was measured with a ruler from the soil level to the upper part of a shoot (Gornik and Grzesik, 2002). Electrolyte leakage was assessed at $20^{\circ} \mathrm{C}$, with 1 -gram leaf segments placed in test-tubes and $3 \mathrm{ml}$ of distilled water added. The electrolyte leakage was measured after 2 and $4 \mathrm{~h}$, using microcomputer conductivity meter CC-551 Elmetron (Gornik and Grzesik, 2002; Szwonek, 2009). The activities of acid and alkaline phosphatases and RNase in the leaves were examined according to the methods described by Knypl and Kabzinska (1977) (Smolen, 2009). The index of chlorophyll content in the leaves was evaluated using Minolta SPAD-502, Japan. The gas exchange was measured using the gas analyser apparatus TPS-2 (PP Systems, USA) (Kalaji et al., 2012).

The obtained results were analysed using the analysis of variance. The means were separated using Tukey's lowest significant difference (LSD) at an alpha level of 0.05 . The data presented in the graphs were expressed also as the average \pm the standard deviation (SD).

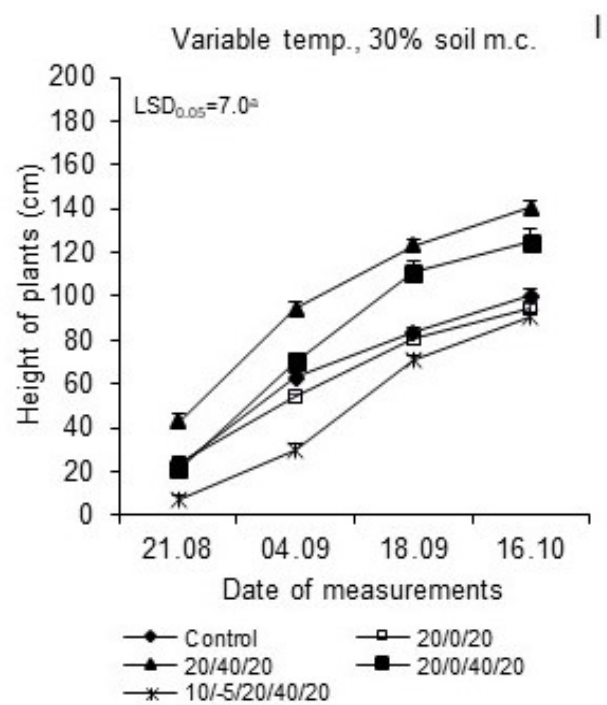

\section{RESULTS AND DISCUSSION}

The tests used to assess plant physiological activity are commonly recognized as useful markers of metabolic activity and plant responses to external stimuli (Badek et al., 2014).

The obtained results revealed the legitimacy of the use of cyanobacteria monocultures and Asahi SL and Biojodis in the cultivation of willow plants (Salix viminalis L.), both under optimal and adverse environmental conditions (the latter characterized by extreme temperatures and soil moisture). The studied preparations applied in different forms to plants during the growing season significantly relieved the symptoms of environmental stress, increased plant resistance to diseases and enhanced their metabolic activity. The most promising results were obtained after triple application of Biojodis at the concentration of $1 \%$ to soil or leaves. In the variant with variable temperatures and soil moisture content of $30 \%$, the highest increase in plant growth was observed after application of Biojodis (1\%). A similar effect was obtained using Asahi SL or a mixture of the two cyanobacteria monocultures, as compared with a control series (Figs 1,2). The beneficial effect of the Asahi SL and Biojodis cyanobacteria monocultures markedly improved the growth and physiological functions of the test plants, both under variable temperatures $\left(-5\right.$ to $\left.+40{ }^{\circ} \mathrm{C}\right)$ and at a constant temperature of $20^{\circ} \mathrm{C}$, while under variable soil moisture $(20-60 \%)$ conditions.

The positive impact was also reflected by the increased integrity of the cytoplasmic membranes. Electrolyte leakage from the leaves was lowest after application of Biojodis. After application with Asahi SL or cyanobacteria monocultures, it was still lower than in the control. This indicated lower permeability of cytomembranes in

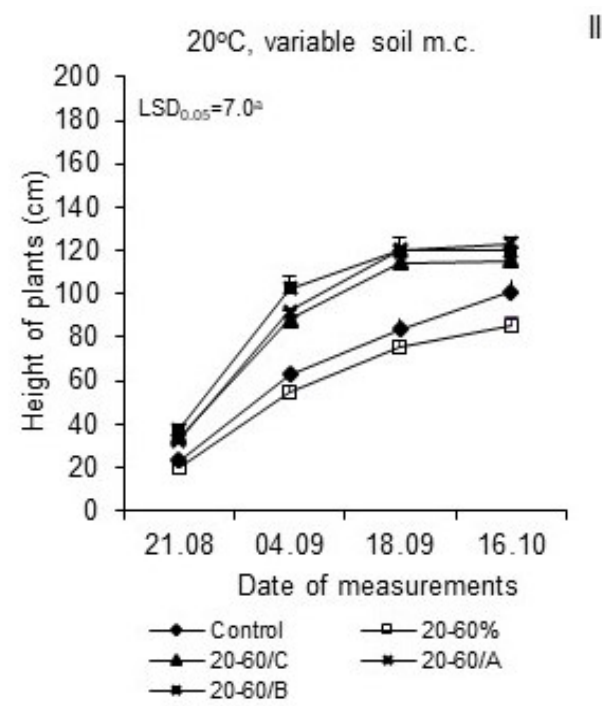

Fig. 1. Height of willow (Salix viminalis L.) plants grown under: I - constant soil moisture content (m.c.) of $30 \%$ and changing temperatures during the first month of growth; II - constant temperature, $20^{\circ} \mathrm{C}$ and periodically changed soil m.c. from 20 to $60 \%$. Additionally, the plants were sprayed three times with cyanobacteria (C), Asahi SL (0.3\%) (A) or Biojodis (1\%) (B). Vertical bars denote \pm SE. LSD at alpha level of 0.05 . 

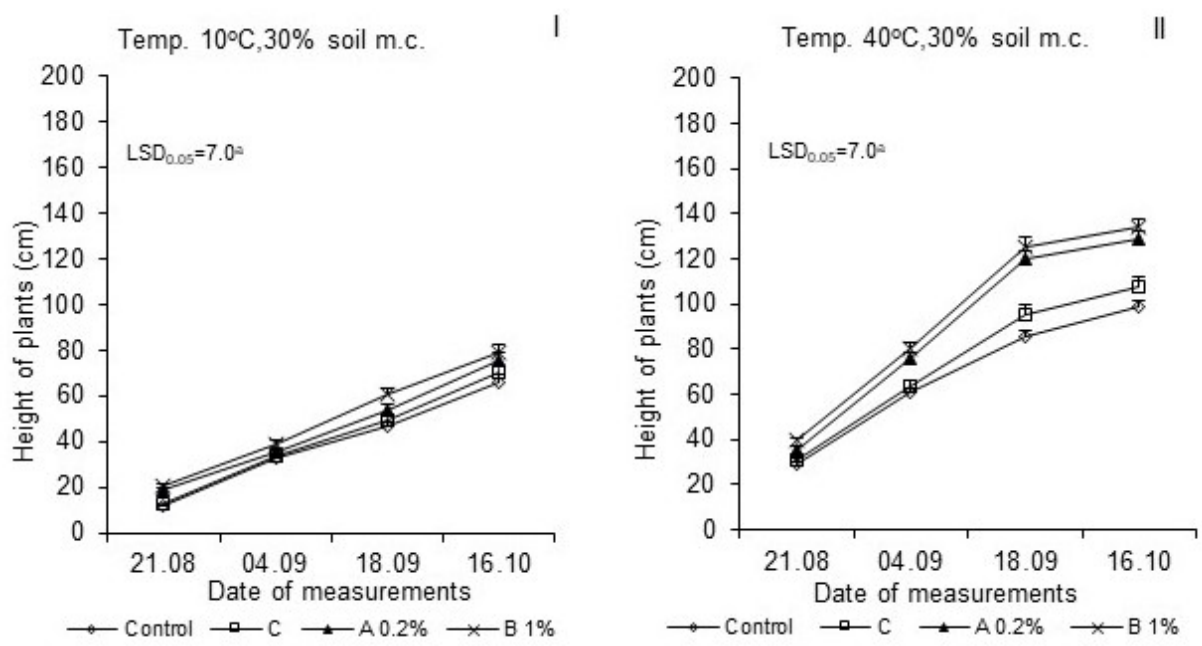

Fig. 2. Height of willow (Salix viminalis L.) plants grown under: $\mathrm{I}-$ constant temperature, $10^{\circ} \mathrm{C}$ and soil moisture content (m.c.) of $30 \%$; II - constant temperature, $40^{\circ} \mathrm{C}$ and soil m.c. of $30 \%$. Explanations as in Fig. 1.
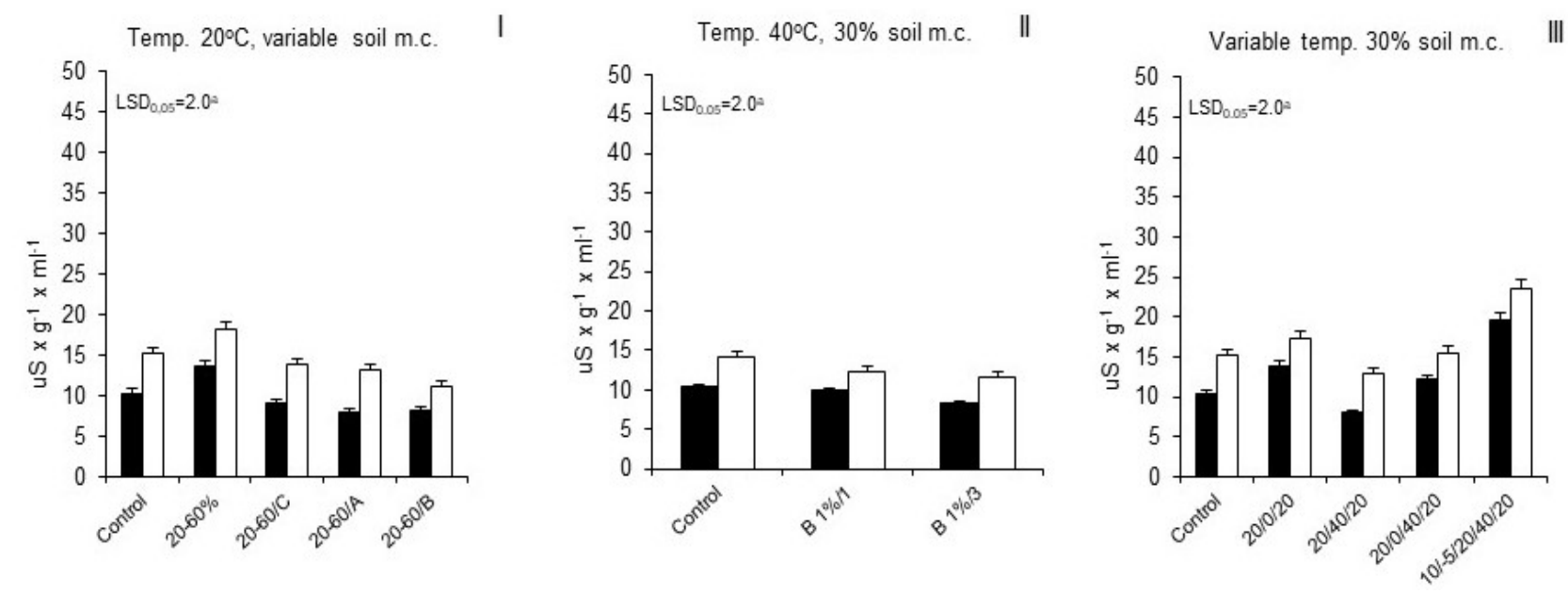

Fig. 3. Electrolyte leakage (after placement in water for 2 and 4 h) from willow (Salix viminalis L.) plants grown under: I - temperature of $20^{\circ} \mathrm{C}$ and in periodically changed soil moisture content from 20 to $60 \%$ m.c. during plant growth - additionally, the plants were sprayed with cyanobacteria (C), Asahi SL (A) or Biojodis (B); II - temperature of $40^{\circ} \mathrm{C}$ and $30 \%$ soil m.c. - the plants were sprayed with Biojodis $(1 \%)$, once $(1 \% / 1)$ and three times $(1 \% / 3)$; III - temperatures changing during the first month and $30 \%$ soil moisture content. Vertical bars denote \pm SE. LSD at alpha level of 0.05 .

the treated variants (Fig. 3). It is important to note that variable temperature $\left(-5\right.$ to $\left.+40^{\circ} \mathrm{C}\right)$ and changing soil moisture content conditions gave rise to weaker plant growth and, in some cases, to complete inhibition of plant development.

The increased activity of enzymes, acid and alkaline phosphatases and RNase confirmed the effectiveness of the used preparations, thus justifying their application in order to increase the resistance of plants to unfavourable conditions resulting from the changing climate. Foliar and soil application of Biojodis (1\%) mostly intensified the enzymatic activity of phosphatases responsible for the management of phosphorus and RNase in plants, the main function of which is the unfolding of phosphodiester bonds in ribonucleic acids (RNA) (Figs 4 and 5). A similar effect was caused by both Asahi SL and a monoculture mixture of cyanobacteria, as compared with the control series.

Variable thermal and moisture conditions adversely affecting willow plant growth, significantly limited its physiological activity. This effect was reflected also by the index of chlorophyll content in the leaves (Fig. 6). The use of the mixture of two cyanobacteria monocultures, as well as the bio-stimulators also resulted in an increase in gas exchange in plant tissues which was expressed by the increased value of net photosynthesis, stomatal conductance, transcription and lower levels of intercellular $\mathrm{CO}_{2}$ (Figs 7 and 8). Biojodis, applied to leaves and soil at the concentration of $1 \%$, was revealed to be the most beneficial with regarded to the growth and physiological activity 

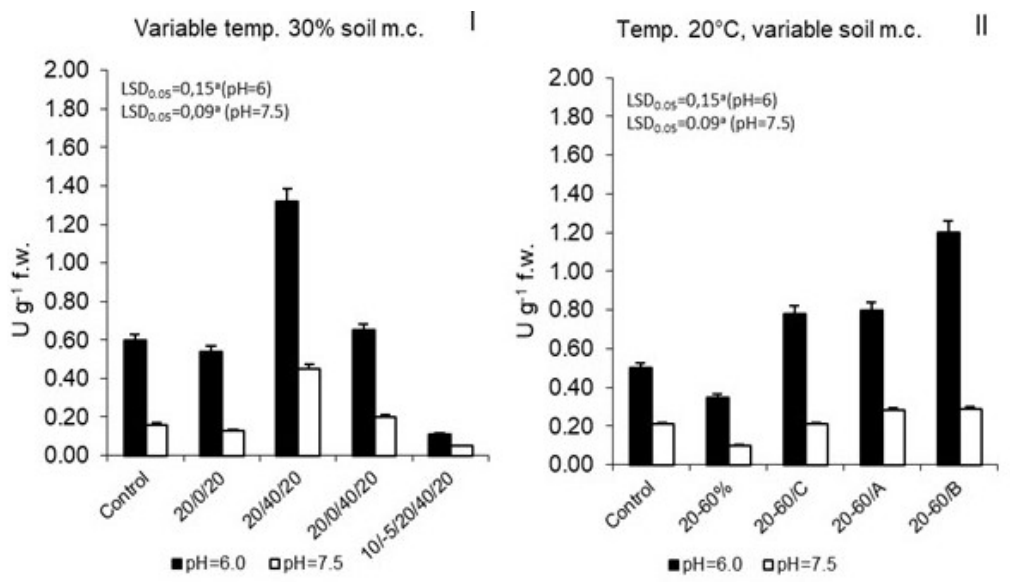

Fig. 4. Activity of acid $(\mathrm{pH}=6)$ and alkaline $(\mathrm{pH}=7.5)$ phosphatase in willow (Salix viminalis L.) plants grown at: $\mathrm{I}-$ variable changing temperature during the first month; II - constant $20^{\circ} \mathrm{C}$ and soil m.c. changed periodically from 20 to $60 \%$ m.c. during plant growth. Explanations as in Fig. 1.
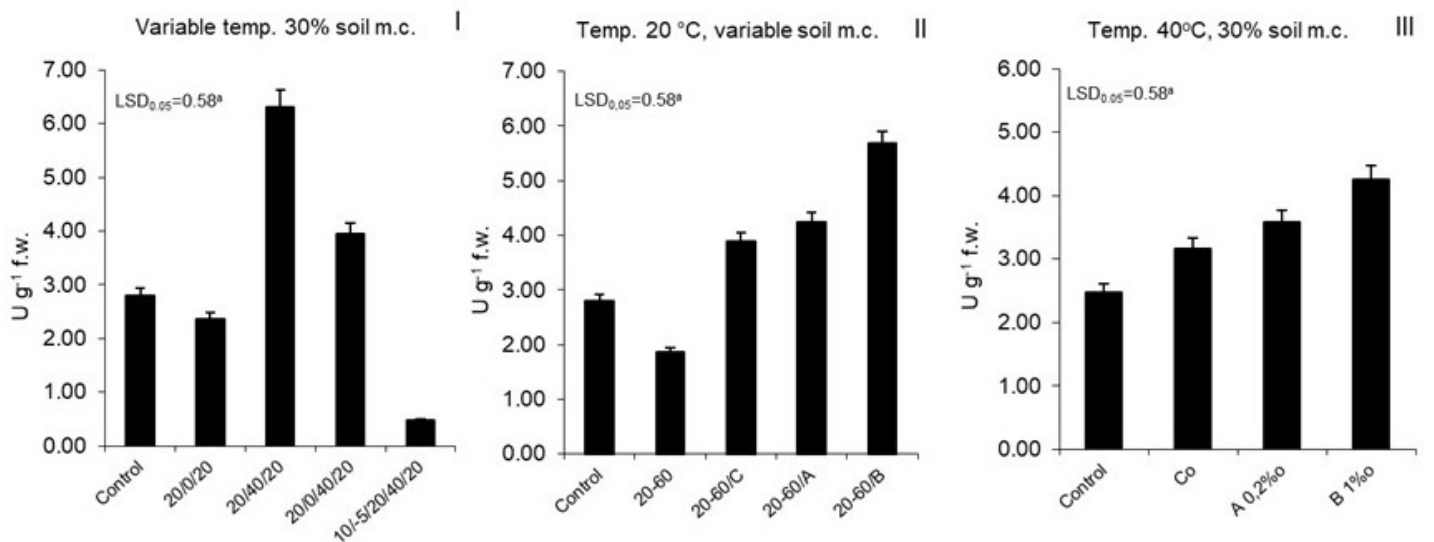

Fig. 5. RNase activity in willow (Salix viminalis L.) plants grown under: I - changing temperatures and $30 \%$ soil m.c.; II - constant $20^{\circ} \mathrm{C}$ and periodically changed soil m.c. from 20 to $60 \%$ - the plants were sprayed with cyanobacteria (C), Asahi SL (0.02\%) (A) or Biojodis (1\%) (B); III - constant $40^{\circ} \mathrm{C}$ and $30 \%$ soil m.c. - the plants were sprayed with cyanobacteria (C), Asahi SL (0.03\%) (A) or Biojodis (1\%) (B). Vertical bars denote \pm SE. LSD at alpha level of 0.05 .
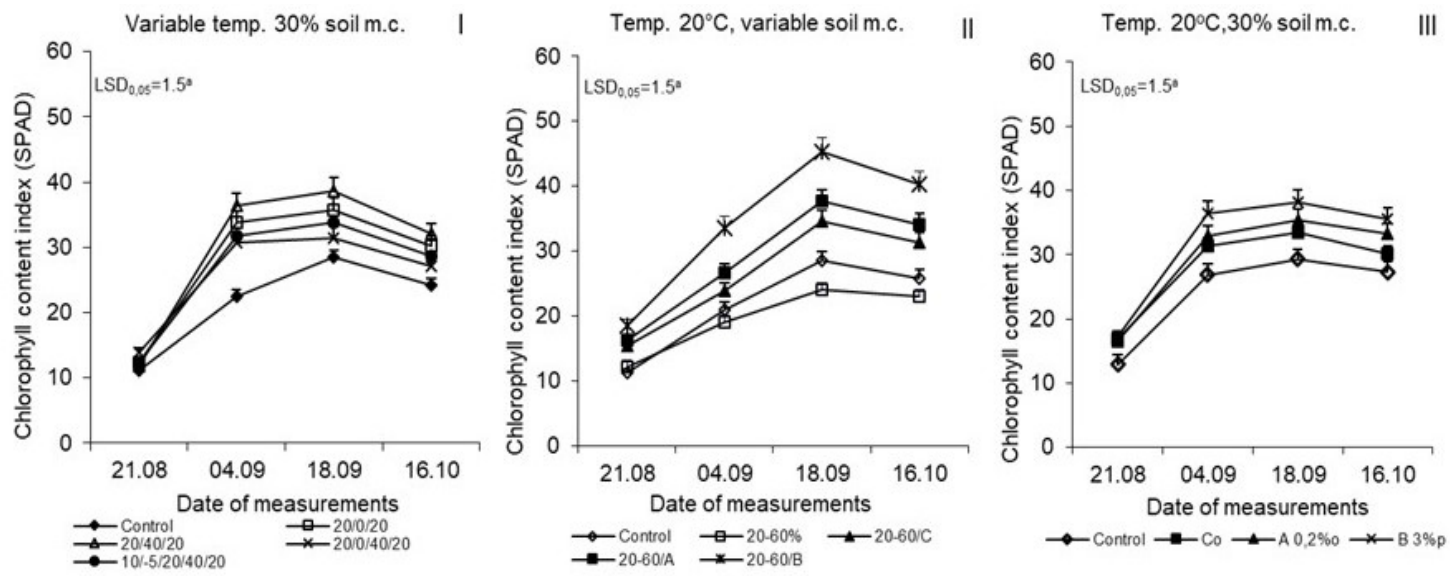

Fig. 6. Chlorophyll content index (SPAD) in willow (Salix viminalis L.) plants grown under: I - variable temperatures and $30 \%$ soil m.c.; II - constant $20^{\circ} \mathrm{C}$ and periodically changed soil m.c. from 20 to $60 \%$ - the plants were sprayed with cyanobacteria (C), Asahi SL $(0.03 \%)(\mathrm{A})$ or Biojodis (1\%) (B); III - constant $20^{\circ} \mathrm{C}$ and $30 \%$ soil m.c. - the plants were sprayed with cyanobacteria (C), Asahi SL $(0.03 \%)(\mathrm{A})$ or Biojodis (1\%) (B). Vertical bars denote \pm SE. LSD at alpha level of 0.05 . 

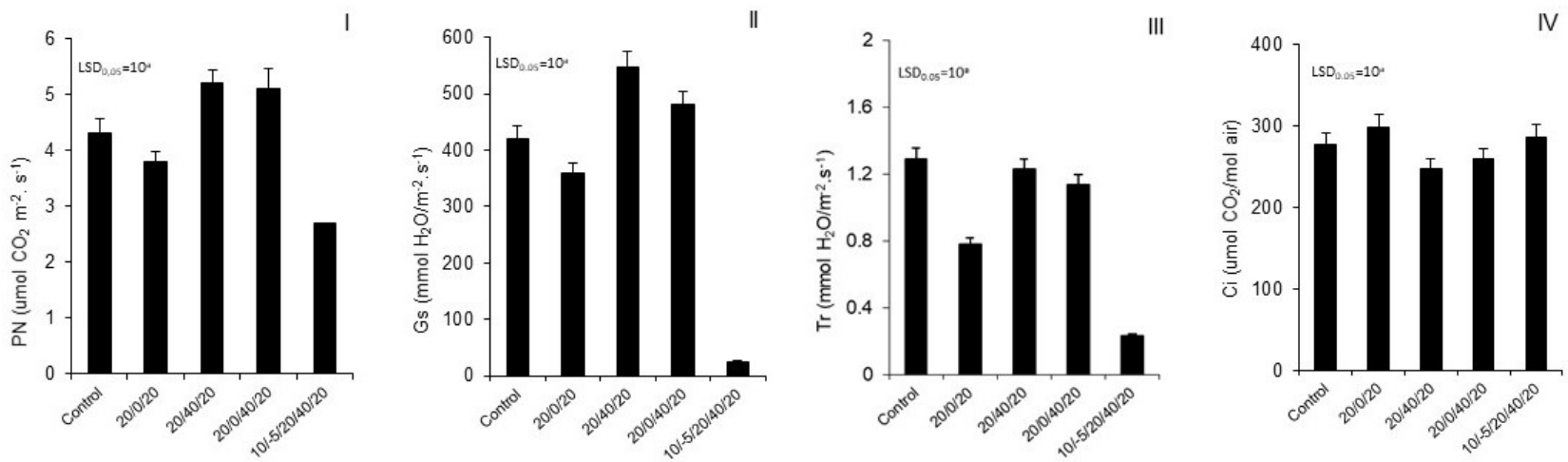

Fig. 7. Net photosynthesis (PN) (I), stomatal conductance (Gs) (II), transpiration ( $\mathrm{Tr})(\mathrm{III})$ and concentration of intercellular $(\mathrm{Cl}) \mathrm{CO}_{2}$ (IV) in willow (Salix viminalis L.). The plants were grown at changing temperatures as of the first month of growth, as well as at soil moisture content of $30 \%$. Vertical bars denote \pm SE. LSD at alpha level of 0.05 .
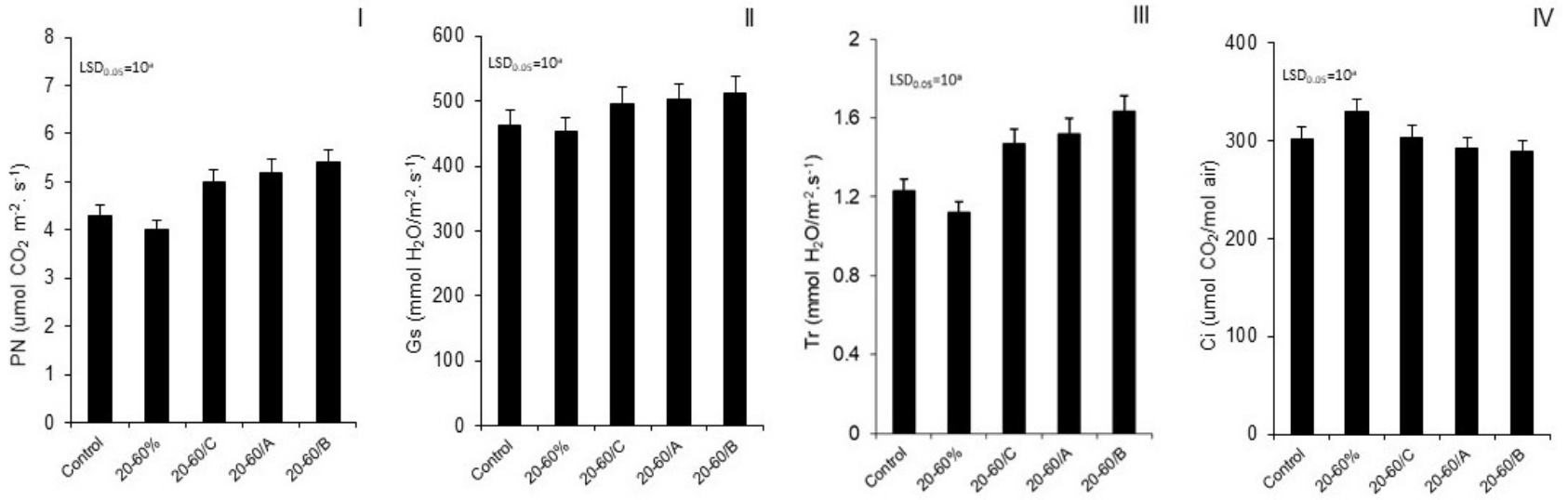

Fig. 8. Net photosynthesis (I), stomatal conductance (II), transpiration (III) and concentration of intercellular $\mathrm{CO}_{2}$ (IV) in willow (Salix viminalis L.) plants grown at a temperature of $20^{\circ} \mathrm{C}$ and in periodically changed soil m.c. from 20 to $60 \%$ m.c. The plants were sprayed with cyanobacteria (C), Asahi SL (0.03\%) (A) or Biojodis (1\%) (B). Vertical bars denote \pm SE. LSD at alpha level of 0.05 .

of plants in all experimental variants. The influence of Asahi SL or a mixture of cyanobacteria monocultures was weaker but still promising. The observed positive effects of Biojodis may be the result of its active iodine content, which is the main component of this preparation. Iodine ions are a component of enzymes and co-enzymes, and take part in many important physiological processes in plants, as well as being involved in basic metabolic processes such as the synthesis of proteins (Jeznach, 2011; Smolen, 2009). These ions also increase the intensity of chemical reactions and stabilise the genetic determinants of different processes at the cellular level. Furthermore, they take an active part in the stabilization of other ions, affect the immune defence in the soil under stress conditions, reduce the permeability of cell membranes in plants and restrict the diffusion of nutrients. Iodine ions also stimulate the regenerative processes in plants, enhancing the synthesis of lignin and polysaccharides (Piotrowski et al., 2016a, b; Smolen et al., 2011).
While having lower potency than Biojodis, Asahi SL also produced favourable effects, as compared to the control. Consisting of active substances from the nitro phenols group, its chemical composition influenced plant growth and development. The application of Asahi SL increased plant growth, intensified the respiratory processes of photosynthesis, improved water management and intensified absorption of nutrients. All the aforementioned effects resulted in higher production of plant biomass. Moreover, this substance reduced the negative effects of adverse environmental conditions and increased the resistance of plants to abiotic stress, primarily to low temperature, excessive moisture and heavy metal concentration. In addition, by way of influencing a number of metabolic processes in plants, it contributed to the reduction of oxidative stress (Anyszka et al., 2008; Gawrońska et al., 2008; Gornik et al., 2007). Previous research has also shown that a single spraying of plants with Asahi SL has a positive effect on seed regeneration, increasing the number and weight of 
seeds and the number of pods (Kocira et al., 2015). Indeed, in our work, the highest seed weight was found with the application of $0.1 \%$ Asahi SL solution, or in our control (Kocira et al., 2015).

It should be noted that our Control (without bio-stimulator or cyanobacteria application) was characterized by the lowest performance factors.

The performed research also indicated the positive effects of the mixture of two cyanobacteria monocultures. It enhanced the growth of the plants and reduced the negative impact of adverse environmental conditions. In addition, the non-toxic cyanobacteria strains (MKR Microcystis aeruginosa 0105 and Anabaena sp. PCC 7120) increased the willow plant (Salix viminalis L.) metabolic activity, as compared to the control series. This positive effect resulted from these strains' ability to synthesize many organic compounds, including the amino acids, carbohydrates, the phytohormones (auxin, gibberellin, cytokinin), macro- and microelements and vitamins, as well as many other secondary metabolites (Piotrowski et al., 2016a, b). These organisms can fix nitrogen from atmosphere and enrich the soil with nitrogen compounds (Haroun and Hussein, 2003; Nain et al., 2010; Perez-Garcia et al., 2011).

\section{CONCLUSIONS}

1. The research performed on willow plants (Salix viminalis L.), cultivated under favourable and unfavourable humidity-thermal environmental conditions, indicated their variable sensitivity to the tested growth stimulants, the mixtures of cyanobacteria, as well as the bio-stimulants Asahi SL and Biojodis. The used cyanobacteria mixtures and bio-stimulant preparations significantly improved plant growth both under favourable and unfavourable conditions of temperature and soil moisture content, and alleviated their negative effects.

2. The used stimulants can become important elements of organic tree-farming. Their application to plants or soil can reduce the use of chemical fertilizers and pesticides, thus significantly decreasing their negative impact on the environment and soil quality. The use of organic fertilizers is one of the most promising strategies for sustainable and integrated crop production in agriculture, forestry and horticulture-

Conflict of interest: The Authors do not declare conflict of interest.

\section{REFERENCES}

Ananieva E.A., Christov K.N., and Popova L.P., 2004. Exogenous treatment with Salicylic acid leads to increased antioxidant capacity in leaves of barley plants exposed to Paraquat J. Plant Physiol., 161, 319-328.

Anyszka Z., Dobrzański A., and Pałczyński J., 2008. The reaction onions and carrots on biostimulant Asahi SL used with herbicides. Conf. Biostimulators in Modern Crop Production, February 7-8, Warsaw, Poland.
Babik J., 2006. Evaluation of the usefulness of Biojodis for use in the cultivation of vegetables. Raport of the Institute of Vegetable Crops, Skierniewice, Poland.

Badek B., Romanowska-Duda Z., Grzesik M., and Van Duijn B., 2014. Rapid evaluation of primed China aster seed (Callistephus chinensis Ness.) germinability using physiological and biochemical markers. J. Horticultural Res., 22(2), 5-18.

Gawrońska H., Przybysz A., and Słowiński A., 2008. Biological basis of action biostimulant Asahi SL. Conf. Biostimulators in Modern Crop Production, February 7-8, Warsaw, Poland.

Gornik K. and Grzesik M., 2002. Effect of Asahi SL on China aster 'Aleksandra' seed yield, germination and some metabolic events. Acta Physiologiae Plantarum, 24(4), 379-383.

Gornik K., Grzesik M., and Mika A., 2007. Improvement of grapevines rooting and growth of plants under stress conditions by Asahi SL. Folia Horticulture, 19(2), 57.

Grzesik M. and Romanowska-Duda Z., 2009. The effect of potential climatic changes, Cyanobacteria, Biojodis and Asahi SL on development of the Virginia fanpetals (Sida hermaphrodita) plants. Pamiętnik Puławski, 151, 483-491.

Grzesik M. and Romanowska-Duda Z., 2014. Improvements in germination, growth, and metabolic activity of corn seedlings by grain conditioning and root application with cyanobacteria and microalgae. Pol. J. Environ. Stud., 23(4), 1147-1153.

Grzesik M., Romanowska-Duda Z., Piotrowski K., and Janas R., 2015. Diatoms (Bacillariophyceae) as an effective base of a new generation of organic fertilizers. Przemysł Chemiczny, 94(3), 391-396, DOI: 10.15199/62.2015.3.27

Grzesik M., Romanowska-Duda Z. and Piotrowski K., 2009. The effect of potential change in climatic conditions on the development of the energy willow (Salix viminalis) plants. Proc. 2nd Int. Conf. Environmental Management, Engineering, Planning and Economics (CEMEPE) and SECOTOX Conf., Mykonos, June 21-26, GRAFIMA Publ., D. Gounari, Thessaloniki, Greece.

Grzesik M., Romanowska-Duda Z. and Piotrowski K., 2011. Influence of Biojodis on the physiological activity of corn plants in the predicted environmental constraints. 15th Int. Symp. Toxicity Assessment, ISTA, July 3-8, Hong Kong.

Haroun S.A. and Hussein M.H., 2003. The promotive effect of algal biofertilizers on growth, protein pattern and some metabolic activities of Lupinus termis plants grown in siliceous soil. Asian J. Plant Sci., 2(13), 944-951.

Hussain A. and Hasnain S., 2012. Comparative assessment of the efficacy of bacterial and cyanobacterial phytohormones in plant tissue culture. World J. Microbiol. Biotechnol., 28, 1459-1466.

Jeznach A., 2011. Effect of iodine on the cabbage fruits ontogenesis and seed quality (in Polish). M.Sc. Thesis, WSEH Skierniewice, Poland.

Kalaji M.H., Schansker G., Ladle R.J., Golt-Sev V., Boska K., Allakhverdiev S., Brestic M., Bussotti F., Calatayud A., Dabrowski P., Elsheery N., Ferroni L., Guidi L., Hogewoning S.W., Jajoo A., Misra A.N., Nebauer S.G., Pancaldi S., Penella C., Poli D., Pollastrini M., Romanowska-Duda Z.B., Rutkowska B., Serodio J., Suresh K., Szulc W., Tambussi E., Yanniccari M., and 
Zivcak M., 2014. Frequently Asked Questions about chlorophyll fluorescence: practical issues. Photosynthesis Res., 122, 121-158.

Knypl J.S. and Kabzinska E., 1977. Growth, phosphatase and ribonuclease activity in phosphate deficient Spirodela oligorrhiza cultures. Biochem. Physiol. Pflanzen., 17, 279-287.

Kocira A., Kocira S., and Stryjecka M. 2015. Effect of Asahi SL application on common bean yield. 7th Int. Sci. Symp. Farm Machinery and Processes Management in Sustainable Agriculture, Agriculture and Agricultural Science Procedia, November 25-27, Gembloux, Belgium.

Li X., Brestic M., Tan DX, Zivcak M., Zhu X., Liu S., Song F., Reiter RJ., and Liu F., 2017. Melatonin alleviates low PS I limited carbon assimilation under elevated $\mathrm{CO}_{2}$ and enhances the cold tolerance of offspring in chlorophyll b-deficient mutant wheat. J. Pineal Res., DOI: 10.1111/ jpi. 12453

Nain L., Rana A., Joshi M., Jadhav S.D., Kumar D., Shivay Y.S., Paul S., and Prasanna R., 2010. Evaluation of synergistic effects of bacterial and cyanobacterial strains as biofertilizers for wheat. Plant Soil, 331, 217- 230.

Perez-Garcia O., Escalante F.M.E., De-Bashan L.E., and Bashan Y., 2011. Heterotrophic cultures of microalgae: Metabolism and potential products. Water Res., 45, 11-36.

Piotrowski K., Romanowska-Duda Z., and Grzesik M., 2016a. How Biojodis and Cyanobacteria alleviate the negative influence of predicted environmental constraints on growth and physiological activity of corn plants. Pol. J. Environ. Stud., 25(2), 741-751, DOI: 10.15244/pjoes/60894

Piotrowski K., Romanowska-Duda Z., and Grzesik M., 2016 b. Cyanobacteria, Asahi SL and Biojodis as stimulants improving growth and development of the Sida hermaphro- dita L. Rusby plant under changing climate conditions. Przemysł Chemiczny, 95/8, 1569-1573, DOI: 10.15199/ 62.2016.8.31

Romanowska-Duda Z., Grzesik M., Owczarczyk A., and Mazur-Marzec H., 2010. Impact of intra and extracellular substances from Cyanobacteria on the growth and physiological parameters of grapevine (Vitis vinifera). 20th Int. Conf. Plant Growth Substance (IPGSA), Book of abstracts July 28 - August 2, University Rovira and Virgili, Tarragona, Spain.

Smolen S., 2009. Effect of nitrogen and iodine fertilization on the mineral content in carrot. Ochrona Środowiska i Zasobów Naturalnych, 40, 270-277.

Song W.Y., Yang H.Ch., Shao H.B., Zheng A.Z., and Brestic M., 2014. The Alleviative effects of salicylic acid on the activities of catalase and superoxide dismutase in malting barley (Hordeum uhulgare L.) seedling leaves stressed by heavy metals. CLEAN - soil, air, water, 42(1), 88-97, DOI: 10.1002/clen.201200310

Szwonek E., 2009. Impact of Foliar Fertilizer Containing Iodine on "Golden Delicious" Apple Trees. Proc. Int. Plant Nutrition Colloquium, XVI, Department of Plant Sciences, US Davis, CA, USA.

Wu W., Zhang Q., Ervin E.H., Yang Z., and Zhang X., 2017. Physiological mechanism of enhancing salt stress tolerance of perennial ryegrass by 24 -Epibrassinolide. Front. Plant Sci., 8, 1017, DOI: 10.3389/fpls.2017.01017

Zarzecka K., Gugala M., Sikorska A., Mystkowska I., Baranowska A., Niewęgłowski M., and Dołęga H., 2017. The effect of herbicides and biostimulants on polyphenol content of potato (Solanum tuberosum L.) tubers and leaves. J. Saudi Soc. Agric. Sci., http://dx.doi.org/10.1016/j. jssas.2017.02.004 